\title{
Studies on In Vitro Propagation Methods in Cactus Species of the Genera Melocactus, Cereus and Lobivia
}

\author{
T. Monostori, L. Tanács and L. Mile \\ Institute of Plant Sciences and Environmental Protection, Faculty of Agriculture, \\ University of Szeged \\ Hódmezővásárhely \\ Hungary
}

Keywords: micropropagation, axillary shoot proliferation, callus culture, somatic embryos, vitrification

\begin{abstract}
In vitro propagation methods are frequently used for the conservation of rare cacti and also for the production of plants for commercial purposes. Here we report on the micropropagation by axillary shoot proliferation at the cactus species Melocactus salvadorensis, Lobivia tegeleriana and Cereus jamacaru being important as ornamentals and also as a forage and fruit crop in the case of the latter one. Depending on species, explants were derived from surface-sterilized shoots or seedlings germinated in vitro. Transverse or longitudinal slices of donor shoots were incubated on MS media supplemented with 1, 2 or $4 \mathrm{mg} \mathrm{L}^{-1}$ BAP. Addition of NAA $\left(0.1 \mathrm{mg} \mathrm{L}^{-1}\right)$ had positive effect on shoot induction. A $50 \%$ reduction of basal salt, vitamin and sugar concentration of hormone-free MS medium helped vitrified or abnormal shoots of $C$. jamacaru to recover and significantly improved rooting rate. Hyperhydricity was frequently observed among adventitious shoots induced on secondary explants of $L$. tegeleriana, while it did not occur in M. salvadorensis. Besides micropropagation, somatic callus cultures of $L$. tegeleriana have also been generated to develop a plant - cell - plant system. Somatic cell cultures make possible manipulations at the cellular level and production of somaclonal variants of interest to cactus enthusiasts. Using MS-based induction media supplemented with 2,4-D ( 2 or $\left.4 \mathrm{mg} \mathrm{L}^{-1}\right)$ calli of granular structure were produced after the passage on MS medium containing 1-1 $\mathrm{mg} \mathrm{L}^{-1}$ 2,4-D and kinetin, respectively. Vigorously growing plantlets of normal morphology have been regenerated on this medium, while plantlets regenerated from calli transferred to hormone-free MS medium grew slower and exhibited abnormal characteristics.
\end{abstract}

\section{INTRODUCTION}

In vitro propagation methods have an increasing importance in cacti through offering an alternative to common propagation methods in cases such as low seed production and germination rate, slow seedling growth or low multiplication rate achieved by cuttings (for reviews, see: Fay and Gratton, 1992). Micropropagation by axillary shoot proliferation is primarily applied for the conservation of rare and endangered species (Ramirez-Malagon et al., 2007). In addition, the aim can be the mass propagation of plants for commercial purposes (Pérez-Molphe-Balch et al., 2002; Sanchez-Martinez and Hernandez-Martinez, 2002). Somatic embryogenesis-based plant regeneration has also been reported in several cactus species (Santacruz-Ruvalcaba et al., 
1998). Callus cultures were used as target tissues to produce transgenic plants in economically important cacti (Al-Ramamneh et al., 2006; Silos-Espino et al., 2006).

Melocactus species are among the most remarkable cacti which develop a cephalium bearing the flowers after reaching the full body size. In addition to late flowering, the germination capacity is usually far below $100 \%$. They never generate offshoots. From this genus the micropropagation of $M$. bellavistensis has been reported up to now (Hernández et al., 1994). Cereus jamacaru is an ornamental plant which also has a remarkable potential as forage and fruit crop or as crossing partner in the breeding of $C$. peruvianus (Mizrahi and Nerd, 1999). It can be propagated by seeds and cuttings but the appearance of both the flowers and the offshoots can be expected after several years of development only. From the Cereus genus only the micropropagation of $C$. peruvianus has been reported so far (Machado and Prioli, 1996). Lobivia tegeleriana (syns.: Acantholobivia tegeleriana, Echinopsis tegeleriana) can be propagated by seeds but never or rarely brings offshoots. To date, no reports on in vitro cultures have been published in species belonging to either genus of the synonyms.

Here we report on the micropropagation by axillary shoot proliferation at the cactus species $C$. jamacaru, $M$. salvadorensis and $L$. tegeleriana. Besides micropropagation, somatic callus cultures of $L$. tegeleriana have also been generated to develop a plant - cell - plant system. This makes the manipulations on cell level and the production of somaclonal variants being interesting for cactus enthusiasts possible. The results achieved here can be used as model for other species of the same genera.

\section{MATERIALS AND METHODS Plant material}

C. jamacaru and L. tegeleriana seedlings $(1-2 \mathrm{~cm})$ with spines cut short were surface-disinfected in $0.5 \%$ Na-hypochlorite for 15 minutes. Tween $80(0.1 \%)$ was added as surfactant. Disinfection was followed by $3 \mathrm{x}$ rinsing in sterile distilled water. Sterilized seedlings were cut into transverse $(C . j$.) or longitudinal (L.t.) slices (1-2 mm thick, 5-10 areolas/explant). In the studies on somatic callus culture, L. tegeleriana shoots of in vitro origin cut into transverse slices were used.

M. salvadorensis seedlings from in vitro germination were cut into transverse slices. Seed disinfection was performed as described above for seedlings but the concentration of Na-hypochlorite was $2 \%$ here.

\section{Culture media}

1. Media used in the micropropagation experiments. MS medium (Murashige and Skoog, 1962) of full or reduced (50\%) macro-, microelement and vitamin concentration (MS and 0.5MS, respectively) with 3\% sucrose was used as basic medium.

Induction media: MS basic media were supplemented with the following combinations of benzylaminopurine (BAP) and naphthalene acetic acid (NAA):

- 1, 2 or $4 \mathrm{mg} \mathrm{L}^{-1}$ BAP: MS1B, 0,5MS1B, MS2B, 0,5MS2B, MS4B medium

- 1,2 or $4 \mathrm{mg} \mathrm{L}^{-1} \mathrm{BAP}+0.1 \mathrm{mg} \mathrm{L}^{-1} \mathrm{NAA}$ : MS1BN, 0,5MS1BN, MS2BN, 0,5MS2BN, MS4BN medium

Rooting media: MS and $0.5 \mathrm{MS}$ media were prepared with $1.5 \%$ sucrose, without growth regulators (MS0 or $0,5 \mathrm{MS} 0$ ) or supplemented with $1 \mathrm{mg} \mathrm{L}^{-1} \mathrm{NAA}$ (MSN or $0.5 \mathrm{MSN}$ ).

2. Media used in somatic callus culture experiments. MS medium with $3 \%$ sucrose was used as basic medium. 
Induction media: MS basic media were supplemented with the following combinations of 2,4-D and kinetin (KIN):

- $2 \mathrm{mg} \mathrm{L}^{-1} 2,4-\mathrm{D}$ or $2 \mathrm{mg} \mathrm{L}^{-1} 2,4-\mathrm{D}+2 \mathrm{mg} \mathrm{L}^{-1} \mathrm{KIN}$ : MS2D or MS2D2K medium

- $4 \mathrm{mg} \mathrm{L}{ }^{-1} 2,4-\mathrm{D}$ or $4 \mathrm{mg} \mathrm{L}^{-1} 2,4-\mathrm{D}+4 \mathrm{mg} \mathrm{L}^{-1} \mathrm{KIN}$ : MS4D or MS4D4K medium

Induction media of reduced hormone content with normal or increased $\mathrm{CuSO}_{4}$ concentration were supplemented as follows:

- $1 \mathrm{mg} \mathrm{L}^{-1} 2,4-\mathrm{D}+1 \mathrm{mg} \mathrm{L}{ }^{-1} \mathrm{KIN}: \mathrm{MS} 1 \mathrm{D} 1 \mathrm{~K}$ or MS1D1K $+5 \mu \mathrm{M} \mathrm{CuSO}_{4}: \mathrm{MS}_{\mathrm{D}} 1 \mathrm{KCu}$

Regeneration media: hormone-free $0.5 \mathrm{MS}$ medium was prepared with $1,5 \%$ sucrose $(0,5 \mathrm{MS} 0)$, in one set of experiments $5 \mu \mathrm{M} \mathrm{CuSO}_{4}$ was added $(0,5 \mathrm{MSCu})$.

\section{Tissue culture methods}

1. Micropropagation via axillary shoot propagation. Explants were incubated on the induction medium at $25{ }^{\circ} \mathrm{C}$ and $16 \mathrm{~h}$ photoperiod. Axillary shoots $(0.5-1 \mathrm{~cm})$ were transferred to rooting medium and incubated at $25^{\circ} \mathrm{C}$ and 16 hours illumination.

2. Callus induction and plant regeneration. Explants were incubated on the induction medium at $25{ }^{\circ} \mathrm{C}$ in the dark for ca. 28 days. Both calli and non-responsive structures were transferred to the induction medium of reduced hormone concentration and incubated at $25{ }^{\circ} \mathrm{C}$ and $16 \mathrm{~h}$ photoperiod. Embryogenic structures were transferred to regeneration medium at a diameter of ca. $2 \mathrm{~mm}$.

\section{RESULTS}

\section{Micropropagation via axillary shoot proliferation}

First shoots of C. jamacaru appeared after 10-14 days of culture. On media of reduced salt and vitamin concentration the induction started later, the number and size of shoots was lower. Calli appeared on the cut surface of the explants only and hyperhydricity (vitrification) occurred at few shoots here (data not shown). NAAsupplement in the induction medium improved while reduction of basic medium concentration reduced shoot formation capacity of the explants. Best result has been achieved on MS2BN medium (Fig. 1-2).

In the studies on rooting efficiency of $C$. jamacaru, the best induction medium $(\mathrm{MS} 2 \mathrm{BN})$ and its NAA-free version were used. Shoots transferred to rooting media continued growing, irrespective of their original size $(0.5-1.0 \mathrm{~cm})$. Rooting started within 14 days. Reduced salt and vitamin content of the rooting medium improved rooting rate. Shoots transferred from NAA-containing induction medium exhibited higher rooting capacity, achieving the highest value (70\%) on $0.5 \mathrm{MS} 0$ medium (Fig. 1).

Axillary shoots of $M$. salvadorensis appeared relatively late, after 7-8 weeks of culture, first on the MS4BN medium (Fig. 2-3). Shoots grew very slow and they had to be transferred to fresh induction medium after 14 weeks of culture. The new medium contained lower concentration of BAP (MS1BN) to prevent vitrification. Here adventitious shoots appeared but only on axillary shoots transferred from the original medium of higher BAP concentration. Due to their slow growth, shoots could be transferred to rooting medium after 10-12 weeks only. Rooting was effective (85-100\%) on both rooting media irrespective of the hormone content of the induction media.

Axillary shoots of L. tegeleriana appeared after 2-3 weeks of culture, first on the MS4BN medium. Their number per explant was higher here, too (Fig. 2). Shoots were transferred to induction medium of halved BAP concentration on the 8th week of culture. Adventitious offshoots appeared on transferred shoots. Their number was higher on those originating from induction media of higher BAP content (MS4BN). Vitrification was a 
common feature of the adventitious shoots. On 38\% of the offshoots root formation started prior to the transfer to rooting medium. All of the shoots exhibiting normal phenotype developed roots on rooting media while vitrification reduced rooting rate to $28 \%$ (data not shown).

\section{Somatic callus cultures of $L$. tegeleriana}

Callus formation started in the first two weeks of culture. These calli were hard but not granular type and covered the whole surface of the explants irrespective of their origin (shoot apex, middle or basal part). They could be observed only on induction media with 2,4-D and KIN supply. On explants incubated on KIN-free media no or very little soft calli appeared. After the transfer to induction medium of reduced 2,4-D and KIN content (MS1D1K), callus formation started on these non-responsive explants, too. These calli were friable and of the embryogenic type, irrespective of the application of increased $\mathrm{CuSO}_{4}$ concentration (data not shown). Hard calli developed already in the first step of induction grew further on MS1D1K but their development did not switch to the embryogenic way. Thus they were not transferred to regeneration medium (Tab. 1).

Samples containing 15-15 pieces of embryogenic structures were transferred from MS1D1K to hormone-free regeneration medium. Shoot or plant regeneration could be detected at $60-67 \%$ of these structures (Tab. 1). These regenerated exemplars grew very slow and exhibited abnormal characteristics. None of them became suitable to transplanting to soil. In contrast, normal, rooted plantlets regenerated on the MS1D1K $(\mathrm{Cu})$ media. They appeared, however, exclusively in cultures originating from KIN-free induction medium of the first step (Tab. 1).

\section{DISCUSSION}

\section{Micropropagation via axillary shoot proliferation}

The macro-, microelement, vitamin and hormone composition of our induction media is similar to those widely used in the micropropagation of cacti (Pérez-MolpheBalch et al., 2002). In C. peruvianus cultures the highest rate of shoot induction was achieved with $1 \mathrm{mg} \mathrm{L}^{-1}$ BAP and $1 \mathrm{mg} \mathrm{L}^{-1}$ NAA the latter being of higher concentration than $0,1 \mathrm{mg} \mathrm{L}^{-1}$ applied in our induction media for $C$. jamacaru. The authors, however, found each tested hormone combination suitable for application in micropropagation (Machado and Prioli, 1996). Gratton and Fay (1999) found a high concentration of 5-10 $\mathrm{mg} \mathrm{L}^{-1}$ BAP necessary in the case of recalcitrant cactus species. In our preliminary experiments with $C$. jamacaru the $5 \mathrm{mg} \mathrm{L}^{-1}$ BAP resulted in high shoot induction but the rate of callus formation and vitrification also increased significantly (data not shown). In spite of its general application, the effect of NAA on the axillary shoot induction has not been studied in detail in cacti. In contrast to our observations in C. jamacaru, no correspondence between the NAA-concentration and the shoot induction rate has been found in cultures of Sulcorebutia alba, the hormone could be omitted from the medium (Dabekaussen et al., 1991).

In contrast to results obtained in other columnar cacti genera (Pérez-Molphe-Balch et al., 2002), no difference between the shoot forming capacity of explants taken from various parts of the donor shoots has been detected in our $C$. jamacaru cultures (data not shown). In C. peruvianus cultures, however, apical explants did not produce offshoots (Machado and Prioli, 1996).

Based on our preliminary experiments, the rate of hyperhydricity could be reduced by the application of halved sucrose concentration in the rooting media. Gratton 
and Fay (1999) give further hints to solve this regular problem: addition of activated charcoal to the medium, increased agar concentration, partial drying of media prior to passage of cultures and reduction of ion-concentration of culture media. As it was revealed by our results, this latter treatment significantly reduced shoot induction rate in C. jamacaru. At the same time, however, it could have a significant role in the recovery of vitrified shoots if applied in the rooting media. In the case of M. salvadorensis, vitrification could not be observed on axillary shoots even at a high BAP concentration such as $4 \mathrm{mg} \mathrm{L}^{-1}$. In contrast, in M. bellavistensis Hernández et al. (1994) obtained the maximum level of shoot induction with $5 \mathrm{mg} \mathrm{L}^{-1}$ BAP and $1 \mathrm{mg} \mathrm{L}^{-1} \mathrm{NAA}$ but $33 \%$ of these were hyperhydrous. Fewer shoots were formed with $2 \mathrm{mg} \mathrm{L}^{-1}$ isopentenyl adenin (2iP) and $0.3 \mathrm{mg} \mathrm{L}^{-1} \mathrm{NAA}$ but these all were normal.

The highest rooting rate $(70 \%)$ achieved in our experiments with $C$. jamacaru was lower but those of $M$. salvadorensis and $L$. tegeleriana corresponded to the $85-100 \%$ registered in $C$. peruvianus, $M$. bellavistensis and other cactus species (Hernández et al., 1994; Machado and Prioli, 1996; Pérez-Molphe-Balch et al., 1998).

\section{Somatic callus cultures of $L$. tegeleriana}

Our results confirm the majority of earlier results regarding the most effective usage of 2,4-D and KIN combination (occasionally supplemented by NAA) in the induction media applied at other cactus species (for review, see: Santacruz-Ruvalcaba et al., 1998). At Ariocarpus kotschoubeyanus the BAP and NAA combination resulted in a more effective shoot regeneration compared to 2,4-D and KIN (Moebius-Goldammer et al., 2003). In the case of $L$. tegeleriana, however, BAP and NAA are used in the induction of axillary bud proliferation (see above). Increased $\mathrm{CuSO}_{4}$ level has positive effect on regeneration if applied in callus cultures of wheat and other cereals (Purnhauser and Gyulai, 1993). Similarly to the results achieved in rapeseed by the same authors, our results did not confirm the positive effect of this treatment in L. tegeleriana either. A significant difference in responsivity has been found between explants taken from different parts of the cotyledon, epi- and hypocotyl of Selenicereus megalanthus (Pelah et al., 2002). In contrast, explants isolated from the apical, middle and basal part of $L$. tegeleriana donor shoots exhibited no difference in callus forming capacity.

\section{Concluding remarks}

Reduced basic salt and vitamin concentration in the induction medium significantly reduce the induction rate of axillary shoots, while it has positive effect on rooting rate if applied in the rooting medium. Low NAA concentration of induction media has positive effect on axillary shoot proliferation and on the rooting rate of shoots transferred to hormone-free rooting medium

Occurrence of hyperhydricity is species-dependent: it is common in $L$. tegeleriana, was not observed in $M$. salvadorensis, while vitrified shoots of $C$. jamacaru could recover on hormone-free rooting medium

Embryogenic calli of L. tegeleriana, can be induced on explants transferred from KIN-free induction medium to medium of reduced 2,4-D and KIN concentration. If continuing incubation on this medium, plantlets of normal characteristics can be regenerated. Thus, any kind of manipulation performed on calli can be potentially followed by plant regeneration on the very same medium.

\section{Literature Cited}


Al-Ramamneh, E.A., · Sriskandarajah, S. and Serek, M. 2006. Agrobacterium tumefaciens-mediated transformation of Rhipsalidopsis gaertneri. Plant Cell Rep. 25:1219-1225.

Dabekaussen, M.A.A., Pierik, R.L.M., Laken, J.D. van der, Hoek-Spaans, J. (1991): Factors affecting areole activation in vitro in the cactus Sulcorebutia alba Rausch. Sci. Hort. 46: 283-294.

Fay, M.F. and Gratton, J. 1992. Tissue culture of cacti and other succulents: a literature review and a report on micropropagation at Kew. Bradleya 10:33-48.

Gratton, J. and Fay, M.F. 1999. In vitro propagation of succulent plants. In: Hall, R.D. (ed.): Methods in Molecular Biology, Vol. 111: Plant Cell Culture Protocols. Humana Press Inc., Totowa, NJ. Pp. 135-140.

Hernandez Hernandez, J., Ruiz Campos, G. and Sanchez Martinez, E. 1994. Apuntes sobre la propagacion in vitro de Melocactus bellavistensis Rauh et Backeb. del Peru. Botanic Gardens Micropropagation News 1:85-86.

Machado, M.D.P.S. and Prioli, A.J. 1996. Micropropagation of Cereus peruvianus Mill (Cactaceae) by areole activation. In vitro Cell. Dev. Biol.-Plant 32:199-203.

Mizrahi, Y. and Nerd, A. 1999. Climbing and columnar cacti: new arid land fruits. In: Janick, J. (ed.): Perspectives on new crops and new uses. ASHS Press, Alexandria, VA. Pp. 358-366.

Moebius-Goldammer, K.G., Mata-Rosas, M. and Chávez-Avila, V.M. 2003. Organogenesis and somatic embryogenesis in Ariocarpus kotschoubeyanus (Lem.) K. Schum. (Cactaceae), an endemic and endangered Mexican species. In Vitro Cell. Dev. Biol.-Plant 39:388-393.

Murashige, T. and Skoog, F. 1962. A revised medium for rapid growth and bioassays with tobacco tissue cultures. Physiol. Plant. 15:473-497.

Pelah, D., Kaushik, R.A., Mizrahi, Y. and Sitrit, Y. 2002. Organogenesis in the vine cactus Selenicereus megalanthus using thidiazuron. Plant Cell Tiss. Org. Cult. 71:8184.

Pérez-Molphe-Balch, E., Pérez-Reyes M.E., Dávila-Figueroa C. A. and VillalobosAmador E. 2002. In vitro propagation of three species of columnar cacti from the sonoran desert. Hort. Sci. 37:693-696.

Pérez-Molphe-Balch, E., Pérez-Reyes, M.E., Villalobos-Amador, E., Meza-Rangel, E., Morones-Ruiz L. del R. and Lizalde-Viramontes, H.J. 1998. Micropropagation of 21 species of Mexican cacti by axillary proliferation. In Vitro Cell. Dev. Biol.-Plant. 34:131-135.

Purnhauser, L. and Gyulai, G. 1993. Effect of copper on shoot and root regeneration in wheat, triticale, rape and tobacco tissue cultures. Plant Cell Tiss. Org. Cult. 35:131139.

Ramirez-Malagon, R., Aguilar-Ramirez, I., Borodanenko, A., Perez-Moreno, L., BarreraGuerra, J.L., Nunez-Palenius, H.G. and Ochoa-Alejo, N. 2007. In vitro propagation of ten threatened species of Mammillaria (Cactaceae). In Vitro Cell. Dev. Biol.-Plant 43:660-665.

Sánchez-Martínez, E. and Hernández-Martínez, M.M. 2002. Propagation of Mexican cacti threatened with extinction. Cact. Succ. J. 74:17-21.

Santacruz-Ruvalcaba, F., Gutiérrez-Mora, A. and Rodríguez-Garay, B. 1998. Somatic embryogenesis in some Cactus and Agave Species. J. Prof. Assoc. Cact. Dev. 3:15-26. 
Published in: ACTA HORTICULTURAE (ISSN: 0567-7572) 937: pp. 255-261. (2012)

Silos-Espino, H., Valdez-Ortiz, A., Rascón-Cruz, Q., Rodríguez-Salazar, E. and ParedesLópez, O. 2006. Genetic transformation of prickly-pear cactus (Opuntia ficus-indica) by Agrobacterium tumefaciens. Plant Cell Tiss. Org. Cult. 86:397-403. 
Published in: ACTA HORTICULTURAE (ISSN: 0567-7572) 937: pp. 255-261. (2012)

\section{$\underline{\text { Tables }}$}

Table 1. Callus induction and plant regeneration in Lobivia tegeleriana.

\begin{tabular}{cccccc}
\hline $\begin{array}{c}\text { Induction } \\
\text { medium }\end{array}$ & $\begin{array}{c}\text { No. } \\
\text { explants }\end{array}$ & $\begin{array}{c}\text { No. responsive explants on } \\
\text { induction } \\
\text { medium }\end{array}$ & $\begin{array}{c}\text { MS1D1K } \\
\text { medium }\end{array}$ & $\begin{array}{c}\text { No. regenerated plants on } \\
\text { induction } \\
\text { medium }\end{array}$ & $\begin{array}{c}\text { regeneration } \\
\text { medium }^{\mathrm{y}}\end{array}$ \\
\hline MS2D & 14 & - & 14 & 1 & $9(60 \%)$ \\
MS2D2K & 16 & 16 & 16 & - & - \\
MS4D & 16 & - & 16 & 2 & $10(67 \%)$ \\
MS4D4K & 14 & 14 & 14 & - & - \\
Total: & 60 & 30 & 60 & 3 & $19(63 \%)$ \\
\hline
\end{tabular}

${ }^{\mathrm{z}}$ On the basis of hard/friable calli

${ }^{y}$ Samples of 15-15 transferred embryogenic structures 
Published in: ACTA HORTICULTURAE (ISSN: 0567-7572) 937: pp. 255-261. (2012)

\section{Figures}
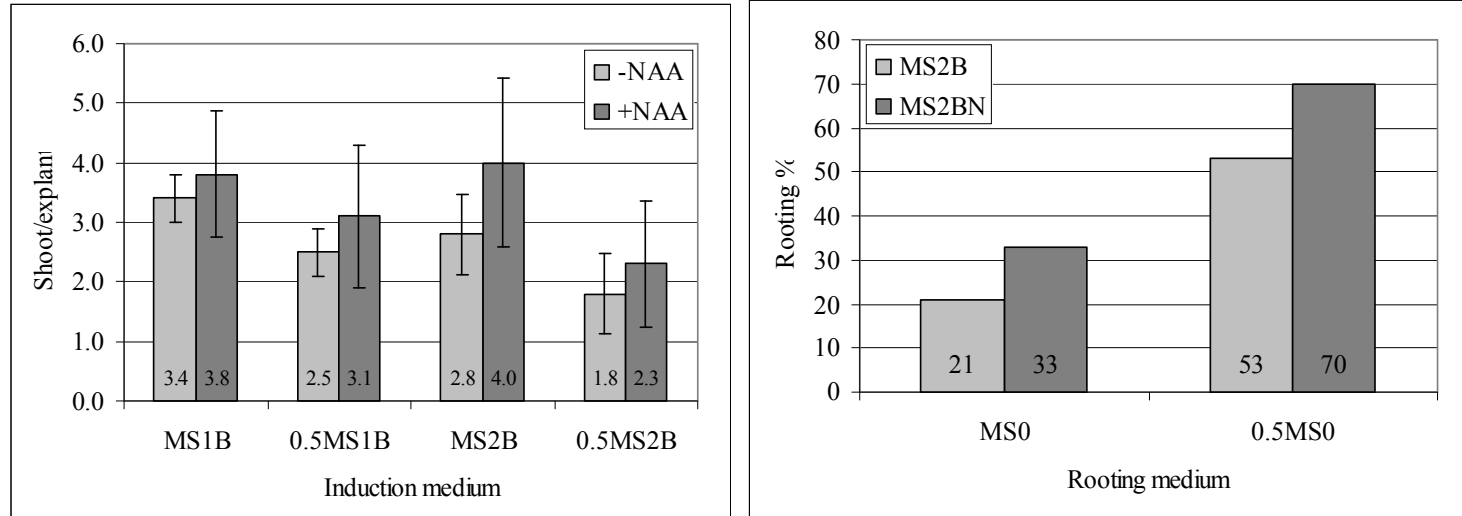

Fig. 1. Cereus jamacaru axillary shoot induction (left) and rooting rate (right) on media of various composition. Error bars represent standard deviation (SD) of the mean.
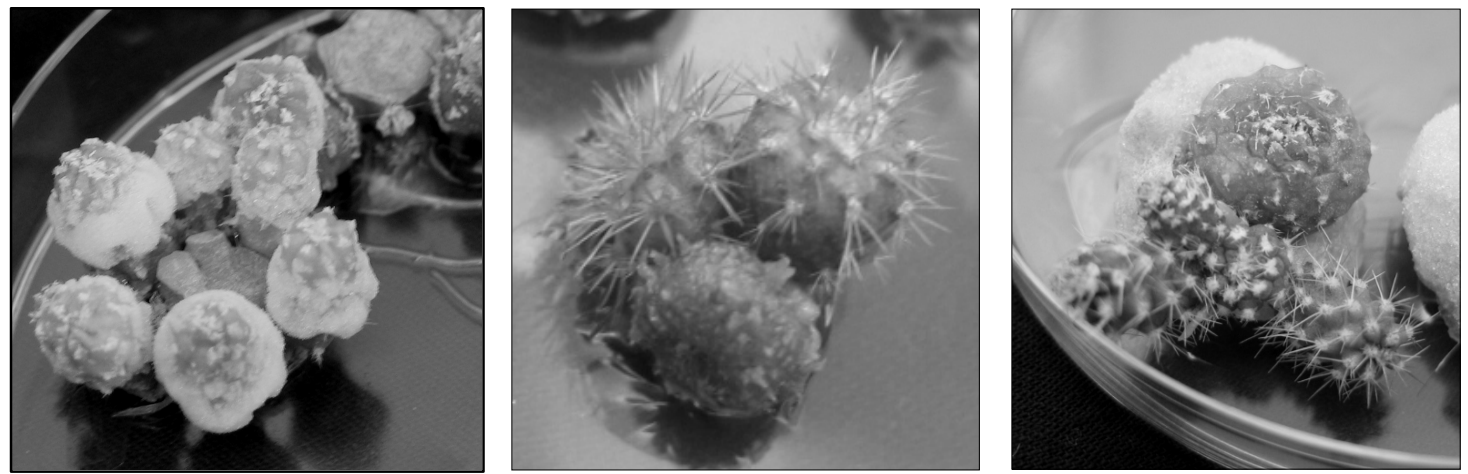

Fig. 2. Axillary shoot induction in C. jamacaru (left), M. salvadorensis (middle) and $L$. tegeleriana (right) on MS2BN, MS1BN and MS4BN induction medium, respectively.
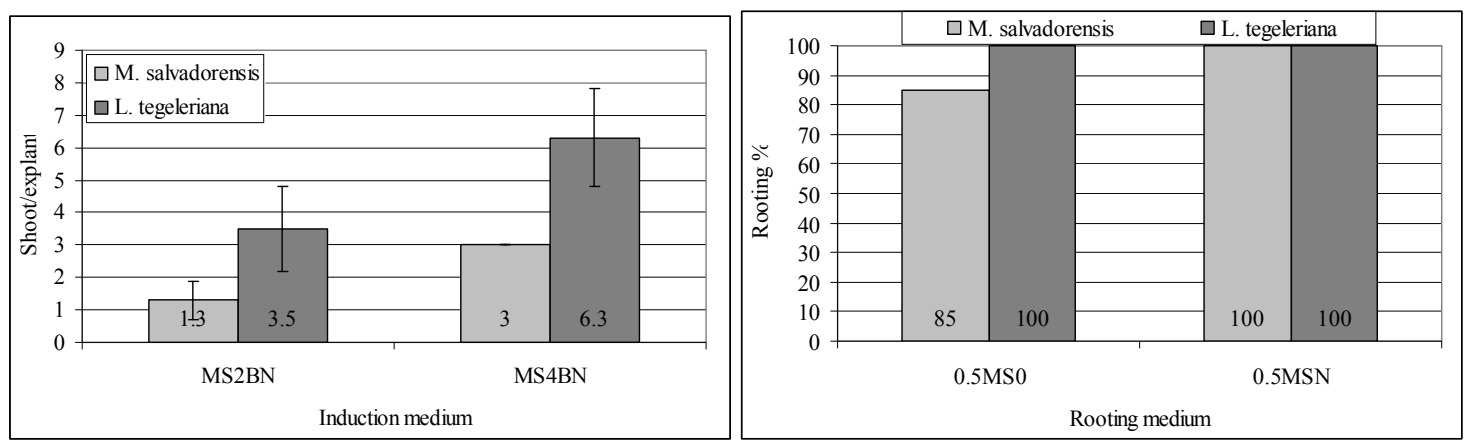

Fig. 3. Melocactus salvadorensis and Lobivia tegeleriana axillary shoot induction (left) and rooting rate (right) on media of various composition. Error bars represent standard deviation (SD) of the mean. 